\title{
BALD EAGLE CONCENTRATION AT HEART LAKE, MANITOBA
}

PETER TAYLOR, P.O. Box 597, Pinawa, Manitoba. ROE 1 LO

Bald Eagles sometimes gather on the Rennie River near Heart Lake, in Whiteshell Provincial Park, during spring migration. ${ }^{2}{ }^{3}{ }^{4}$ Hatch has noted that "the water opens up early here and the eagles concentrate to feed on the dead fish which seem to be particularly prevalent at this spot". ${ }^{3}$ Peak counts of about a dozen birds often occur around 20 April; subadults usually predominate (B. Burwell, D.R.M. Hatch, M. Siepman, D. Whellams, pers. comm.) The highest previous count of which 1 am aware was 5 adults and 13 subadults seen by Hatch and Siepman on 20 April 1982. ${ }^{3}$ This note describes an unusually large gathering in April 1986.

Bud Burwell alerted me to this spectacle. He had counted 26 eagles at Heart Lake on 8 April, and 39 on the morning of 9 April. On the evening of 9 April most of the eagles were standing on the lake ice, in groups of up to ten birds, about 2 $\mathrm{km}$ from the vantage point alongside Provincial Road 307. Less than a quarter of the lake surface was open water. Dozens of Common Ravens and Herring Gulls were also on the ice, and there were small flocks of Common Mergansers in the water.

Up to 45 eagles were counted on repeated scans of the lake with a 30-power telescope. An accurate count was not possible, however, because part of the lake surface was obscured from view, and some eagles were flying back and forth between the ice and the trees surrounding the lake. A few were also scattered along the river. It is estimated that about 60 were probably present, 45 being an absolute minimum. Burwell and I both judged that the numbers of adults and subadults were roughly equal. Around sunset, the eagles left the lake in ones and twos to roost nearby.

Table 1. SUMMARY OF WEATHER CONDITIONS AT WHITESHELL NUCLEAR RESEARCH ESTABLISHMENT, 1-14 APRIL 1986.

\begin{tabular}{|c|c|c|c|c|c|}
\hline \multirow[t]{2}{*}{ Date } & \multirow{2}{*}{$\begin{array}{r}\text { Max. } \\
\text { Temp. }\left({ }^{\circ} \mathrm{C}\right)\end{array}$} & \multirow{2}{*}{$\begin{array}{r}\text { Sunshine } \\
\text { (hours) }\end{array}$} & \multicolumn{2}{|c|}{ Average wind } & Precipitation \\
\hline & & & direction & speed $(\mathrm{km} / \mathrm{h})^{*}$ & \\
\hline 1 & 7.3 & 10.2 & NW & 26 & $\mathrm{Nil}$ \\
\hline 2 & 7.8 & 1.4 & ESE & 23 & $\mathrm{Nil}$ \\
\hline 3 & 11.5 & 6.8 & NE & 15 & Nil \\
\hline 4 & 12.6 & 8.9 & SE & 22 & $0.2 \mathrm{~mm}$ rain \\
\hline 5 & 6.6 & 1.3 & SE & 5 & $\mathrm{Nil}$ \\
\hline 6 & 15.8 & 5.7 & SW & 15 & $4.3 \mathrm{~mm}$ rain \\
\hline 7 & 12.4 & 8.9 & NW & 33 & Trace of rain \\
\hline 8 & 8.9 & 10.8 & NNW & 27 & $\mathrm{Nil}$ \\
\hline 9 & 15.1 & 11.2 & NW & 3 & $\mathrm{Nil}$ \\
\hline 10 & 20.0 & 11.1 & SSE & 13 & $\mathrm{Nil}$ \\
\hline 11 & 16.5 & 3.8 & ESE & 18 & $\mathrm{Nil}$ \\
\hline 12 & -6.1 & 0.0 & NNW & 26 & $3.6 \mathrm{~cm}$ snow \\
\hline 13 & 0.7 & 0.0 & $N$ & 17 & $\mathrm{Nil}$ \\
\hline 14 & 4.8 & 1.2 & NNW & 31 & $\mathrm{Nil}$ \\
\hline
\end{tabular}

* Average of hourly readings between 0800 and 1800 , measured $60 \mathrm{~m}$ above ground. 
On 10 April Martin Siepman saw only 5 adult eagles and about 25 subadults. On 11 April Bruce Stewart saw about 25 subadults only. On 20 April Howard Ross and I saw about nine birds, again all subadults. Chris Pritchard reported about seven dark eagles on 27 April. On 3 May a large group of birders saw only two eagles, passing high overhead. By that time, the rivers and many lakes were largely ice-free.

The concentration of eagles thus appeared to consist of a brief stopover by adult birds and a more leisurely staging by subadults. The small number of Bald Eagles that nest along the Winnipeg River appear to establish nesting territories as soon as they arrive, usually in the second half of March (personal records). Those residing on local lakes may start nesting somewhat later, but the adults at Heart Lake on 9 April 1986 were likely migrating farther north.

Meteorological records from the Whiteshell Nuclear Research Establishment, about $30 \mathrm{~km}$ west-northwest of Heart Lake, provide a plausible explanation for this concentration of eagles. Records are summarized in Table 1.

Early April 1986 was generally sunny, with daily maximum temperatures well above the long-term average of about $6^{\circ} \mathrm{C}$. Winds had a southerly component on four of five days between 2 and 6 April, and unusually early arrivals were noted for many migratory birds in southern Manitoba. The prolonged sunshine and moderate southeasterly wind on 4 April were probably most favorable for Bald Eagles entering the Whiteshell region via northwestern Ontario, as proposed by Gerrard and Hatch. ${ }^{2}$

Conditions deteriorated somewhat on 7 and 8 April, with strong northwesterly winds, while 9 April (when the highest count was made) was largely calm. Good migration conditions occurred again on 10 and 11 April, with the resumption of moderate southeasterly winds. The adult Bald Eagles disappeared at this time, but there was little or no change in the numbers of subadults.

The mild weather ended abruptly when a cold front passed on the evening of 11 April. The air temperature dropped about $15^{\circ} \mathrm{C}$ in two hours, and remained at or below the freezing point for the next two days, with strong northerly winds and heavy cloud-cover, before more seasonal conditions slowly returned. This cold spell presumably hindered further migration or dispersal of the subadult birds, but their migration is less urgent, and known to be somewhat later, than that of adults. ${ }^{2}$

Despite the warm weather in early April, most rivers and lakes were still icebound, and deep snow remained in the forest. The concentration of Bald Eagles thus appears to have resulted from intermittently favorable weather conditions for migration in the first half of April, combined with limited availability of good feeding areas.

I am grateful to Bud Burwell, for promptly telling me about the eagles, and to Phil Davis for access to meteorological records.

1 GERRARD, J.M. and P.N. GERRARD. 1982. Spring migration of Bald Eagles near Saskatoon. Blue Jay 40:97-104.

${ }^{2}$ GERRARD, J.M. and D.R.M. HATCH. 1983. Bald Eagle migration through southern Saskatchewan and Manitoba and North Dakota. Blue Jay 41:146-154.

${ }^{3}$ HATCH, D. 1982. Bald Eagles are thriving in special Whiteshell site. Chickadee Notes, Winnipeg Free Press, 23 April.

${ }^{4}$ KOES, R.F. and P. TAYLOR. 1984. Bald Eagle migration in southeastern Manitoba. Blue Jay $42: 110-112$. 